\title{
Price stabilization policy in an emerging economy: An asymmetric approach
}

\author{
Jaka Sriyana \\ Department of Economics, \\ Islamic University of Indonesia, Indonesia \\ jakasriyana@uii.ac.id
}

Abstract. Price stabilization has been an important issue for Indonesian monetary authority for decades. Relatively high inflation rates in the recent years following a series of financial crises have characterized Indonesian economy. The aim of this paper is to investigate the determinants of inflation dynamics based on the annual data for the period of 1970-2017. The nonlinear autoregressive distributed lag (NARDL) model is applied to identify the dynamic effects of government expenditure, money supply, and exchange rate on the inflation rate. The research finds that the mentioned variables significantly affect the inflation

Received: January, 2019 1st Revision: May, 2019 Accepted: June, 2019

$$
\text { DOI: }
$$

$10.14254 / 2071$ $8330.2019 / 12-2 / 10$ rate. Moreover, the dynamic effects of these variables on the inflation rate are asymmetric in the long run. Positive changes in government expenditure and money supply have a long-run impact on the increase of inflation rate. The increase in inflation rate is also associated with currency depreciation. The international financial market dynamics affects the inflation rate in the country through asymmetric effects of exchange rate volatility. This paper also highlights that government expenditure and money supply are effective instruments for price stabilization, with their asymmetric effects taken into consideration. The evidence of the short-run symmetric impact from those variables implies that fiscal and monetary authorities should have a quick response to the price stabilization.

Keywords: asymmetric effect, exchange rate, fiscal policy, inflation, monetary policy.

JEL Classification: C53, E62, E63

\section{INTRODUCTION}

Price stabilization is the main challenges of macroeconomic policy in developing countries. Fiscal and monetary authorities in some countries are concerned to maintain the inflation rate at a desirable level. Previous studies mention that inflation is a fiscal and monetary phenomena (Halka \& Szafranski, 2018; Kumar, 2015; Mohanty \& John, 2015). Therefore, goods and services prices increases in a country may occur as the impact of expansive fiscal and monetary policy. The expansive fiscal policy which is indicated 
by the increase of government expenditure tends to push the aggregate demand that causes inflation. Another fiscal variable - budget deficit - also influences inflation rate in some countries (Fakher, 2016; Nguyen, 2015). Meanwhile, other papers mention that money supply as the main monetary policy instrument has a strong relationship with inflation rate (Raji, Juzhar \& Jantan, 2014). Another variable, the exchange rate also potentially affects the domestic price level in some countries (Ajaz, Nain \& Kamaiah, 2016).

The inflation rate in Indonesia has been a unique phenomenon for a long-term period of country's development process. At the early stages of the long development plan in the 1970s, the inflation rate reached about 40 percent annually. Responding to the situation, the central government applied prudent fiscal and monetary policies. The combination of these policies caused the inflation rate to drop gradually for at least a decade. The inflation rate in the period of 1980-1990 was recorded at around 10 percent per annum. Unfortunately, the financial crisis of 1998 which damaged most of the Asian countries including Indonesia caused the inflation rate to sharply increase to 70 percent. The central bank of Indonesia practiced tightened monetary policy through raising the interest rate. As a result of this policy, the inflation rate decreased at about 10 percent in three years.

The global financial crisis in 2008 also affected Indonesia's economic situation until the early of the 2010s. The inflation rate increased at around 10 percent on average for five years after. This phenomenon remains to be somewhat challenging for monetary and fiscal authorities of the country. The central government released various fiscal policies to maintain the inflation rate at less than 10 percent. At the same time, the central bank also imposed the new prudential policy with its gradually increased interest rate. As a result, the average inflation rate in the period of 2011-2015 was at a desirable level. Historically, credibility of monetary policy plays an important role in price stabilization in the country. The government's budget plan which contains government expenditure and other macroeconomic assumptions such as economic growth and exchange rate are also the key factors of determining the inflation rate. Previous studies emphasized that credibility of fiscal and monetary policies is an important factor in reducing the inflation rate (Insukindro \& Sahadewo, 2010; Lakić \& Šehović, 2016).

The recent studies regarding price stabilization policy mostly focused on the role of monetary policies. Limited papers mentioned the impact of fiscal variables on the inflation rate. Therefore, the next challenge regarding studies of inflation rate may involve the role of fiscal and monetary policy as well as other economic indicators simultaneously. Other issues that emerge in recent studies are also the responses of government policies on inflation using an asymmetric approach. This research aims to analyze the effects of fiscal and monetary policies as well as an international factor on the inflation rate on the case of Indonesia. The novelty of this paper lies in application of the asymmetric approach to the analysis for all explanatory variables. Therefore, this paper may contribute to literature in part of determining the patterns of government policies responses on the inflation rate. Such research on Indonesian case may be useful for other countries looking for more effective fiscal and monetary policies of price stabilization. The paper is organized as follows. Section 1 presents the introduction. Section 2 highlights the related literature. Section 3 presents data and methodology, meanwhile section 3 provides empirical findings and discussion. Finally, section 4 summarizes the main findings and concludes.

\section{RELATED LITERATURE}

Theoretically, fiscal and monetary variables such as money supply and government expenditure are the main determinants of the inflation rate. Some previous papers have examined the price stabilization policy by examining fiscal and monetary policies in various countries. Several studies confirm a strong relationship between the monetary sector and the inflation rate (Bozkurt, 2014; Nikolaos \& Constantinos, 
2013; Raji et al., 2014). Other papers mention the significant effects of government expenditure on the inflation rate (Fakher, 2016; Khundrakpam, 2010). Moreover, selected papers present the impact of an international factor on price changes and confirm the presence of imported inflation in some countries (Ajaz, Nain, \& Kamaiah, 2016; Berument \& Doan, 2003; Hamilton, 2012). Another international monetary indicator such as exchanges rate is also an important factor in determining the inflation rate (Ghosh, 2014). Based on these references, we may highlight that the inflation rate is closely related to the fiscal and monetary sectors as well as an international factor.

A few papers present the study regarding the inflation dynamic in Indonesia (Hossain, 2005; Insukindro \& Sahadewo, 2010). Meanwhile, other studies concern the behavior of the inflation rate in selected emerging economies including Indonesia (Bhattacharya, 2014; Nguyen, 2015). Hossain (2005) analyzed the relationship between money supply and inflationary rate in Indonesia using a dynamic economic approach. Based on the cointegration and error correction model, the study reveals the presence of a long-run relationship between price and money supply. Specifically, he found a long-run causal relationship between narrow money and price level for the several sub-period samples. On the other hand, Insukindro and Sahadewo (2010) mentioned the quick response of economic agents to anticipate the price changes as an impact of credible monetary policy in Indonesia.

The analysis of inflation rate determinants in various countries generally involves monetary and fiscal variables as well as exchange rate variables. Raji, Juzhar, and Jantan (2014) found a long-run bidirectional causal relationship between money supply and price level based on annual data 1970-2010 in Nigeria. Such phenomena also emerged in India where the monetary variables simultaneously affect the inflation rate (Mohanty \& John, 2015). Another paper provides different result regarding the impact of the money supply on inflation (Bhattacharya, 2014). This study mentions that broad money is not significant as an explanatory variable in an empirical inflation model for selected Asian economies.

Only few papers focus on the role of fiscal policy on price stabilization. Research conducted by Nguyen (2015) highlights that government expenditure strongly affects the inflation rate in selected Asian countries. Moreover, Fakher (2016) also studied the impact of fiscal policy which is represented by government expenditure on inflation in selected Asian countries. Both studies reveal the presence of a cointegrating relationship between government expenditure and inflation rate. Therefore, those researches confirm the long and short-run effects of the fiscal policy on the inflation rate.

The impact of the international factor on inflation is mainly indicated by the exchange rate variable through a financial market mechanism in several countries. The effect of the exchange rate volatility on price level was found by (Findreng, 2014). Meanwhile, Fakher (2016) emphasizes the exchange rate as a determinant of inflation in selected Asian countries. The exchange rate volatility may affect the inflation rate in the country through the international trade mechanism. Moreover, (Ajaz et al., 2016) examined an asymmetric relationship between the exchange rate variable and inflation rate using annual data 1970-2014 for the Indian case. The study revealed the asymmetric effects of exchange rate on inflation both in the short and long-run period. Therefore, the short-run effects of positive and negative changes in the exchange rate on inflation are not equal. The impacts of a positive and negative component of the exchange rate on price change are also not symmetry.

The phenomena of the financial crisis in some countries including Indonesia in 1997 and 2008 were also a potential factor of the inflation rate. Global financial instability as an impact of the financial crisis leads to financial instability in the country (Zwolankowski, 2013). Moreover, the recent study also highlighted the long-run relationship between the international factor and domestic food price (Meyer, Sanusi, \& Hassan, 2018). Specifically, that study presents the effect of world oil price on domestic food price in oil-exporting countries. It may be inferred that open economies countries such as Indonesia 
potentially absorb the global financial volatility to domestic inflation. Therefore, it is reasonable to consider the exchange rate variable as an important factor of inflation rate in this study.

\section{DATA AND METHODOLOGY}

\subsection{Data description}

This study examines the effects of government policies and international factor on the inflation rate in Indonesia based on annual time series data of 1970-2017. The government fiscal policy is indicated by government expenditure on final consumption. Meanwhile, the monetary policy is represented by the amount of money supply. The variable of an international factor is indicated by the exchange rate which is measured by the ratio between the Indonesian currency (Rupiah) and the US dollar. The description of the variables is presented in Table 1. All the data are collected from the annual report of World Development Indicators (https://data.worldbank.org).

Table 1

The Description of examined variables

\begin{tabular}{|l|c|c|}
\hline Variables & Definition & Unit \\
\hline Inflation $\left(i n f_{t}\right)$ & Consumer Prices & $(\%$ annual $)$ \\
\hline Government expenditure $\left(\mathrm{gov}_{t}\right)$ & Total Government Expenditure & $(\%$ of GDP $)$ \\
\hline Money supply $\left(m s_{t}\right)$ & Broad money & $(\%$ of GDP $)$ \\
\hline Exchange rate $\left(e r_{t}\right)$ & Official exchange rate & $($ ratio Rp $/$ US $\$)$ \\
\hline
\end{tabular}

Source: World Development Indicators (https://data.worldbank.org)

The behavior of the examined variables is reported in Figure 1 and Figure2. The exchange rate variable is presented in different figure because it has a different measurement with other variables. As the focus of this study, the inflation rate variable shows the high volatility along the period of 1970-2017 which has two peak points. The first peak point was in 1969 following the political crisis with the inflation level of about 40 percent. At the second peak point in 1998, the inflation rate reached almost 60 percent as an impact of serious monetary crisis which attacked some Asian countries including Indonesia. The other extreme phenomena are the volatility of the money supply and exchange rate data. The money supply variable has its peak level also in 1998 coinciding with the highest inflation rate. The next variable, the exchange rate also exhibits the drastic depreciation of the Indonesian currency in 1998 and 2008. The latest data in 2017 was recorded that the 1 US dollar equals to 13,389 Rupiah. The regional financial crisis in 1997 and the global financial crisis in 2008 have caused high depreciation of Indonesian Rupiah against some international currencies. 


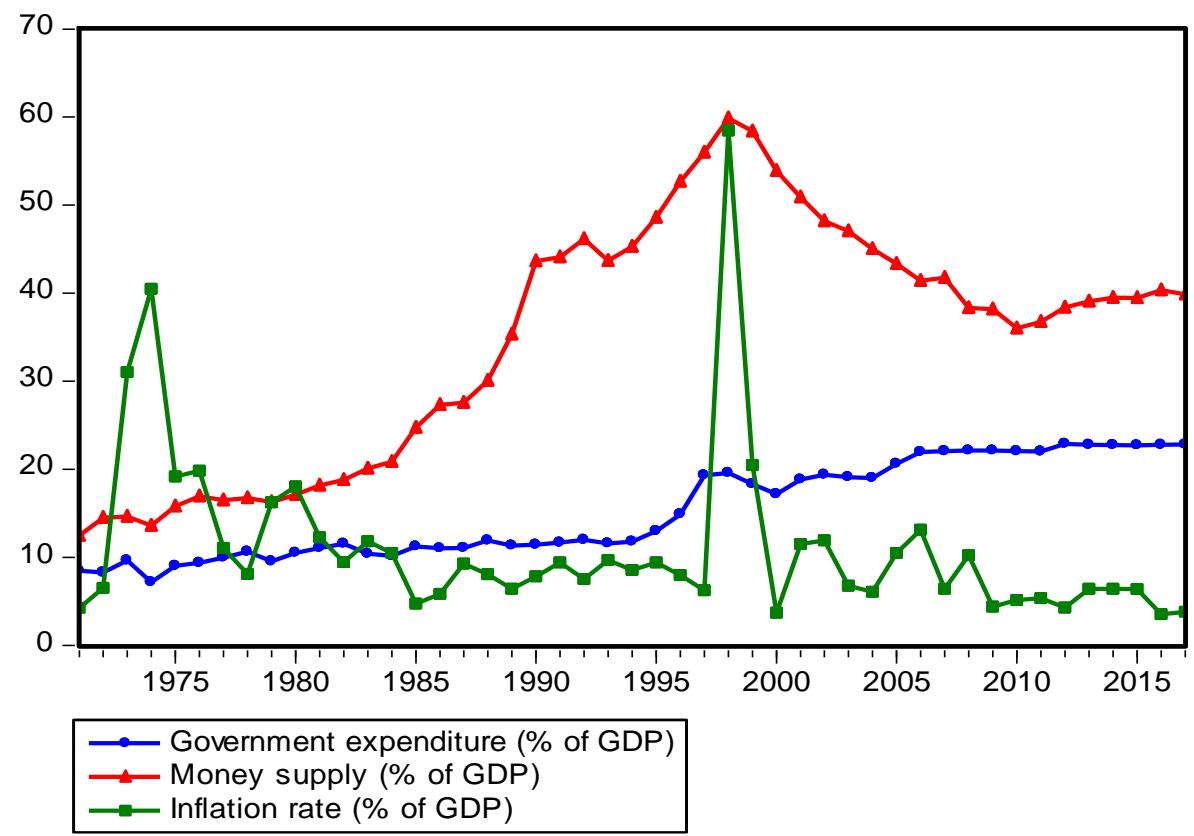

Figure 1. Trend of money supply, inflation, and government expenditure

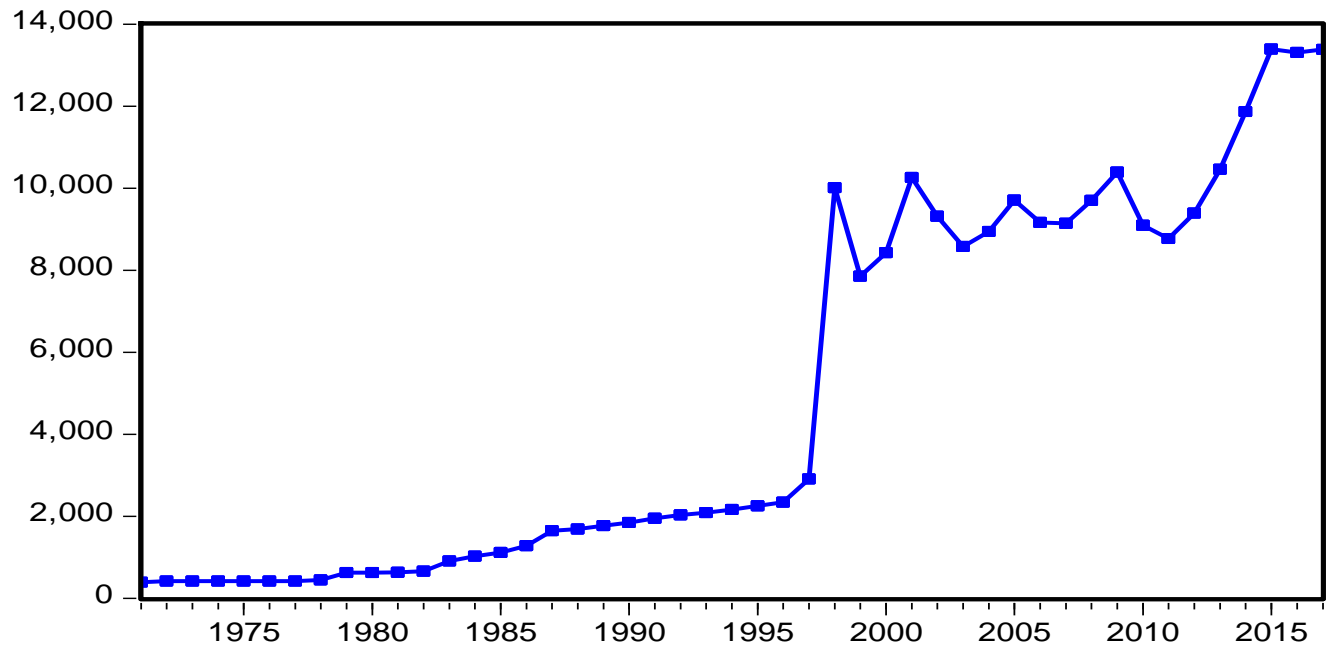

Exchange Rate (Rupiah/1 US \$)

Figure 2. The trend of the exchange rate of the Indonesian currency

\subsection{Methodology}

This study attempts to elaborate the dynamic responses of government expenditure, money supply and exchange rate on the inflation rate using standard nonlinear autoregressive distributed lag (NARDL) model (Shin, Yu, \& Greenwood-Nimmo, 2014). The model has been widely used to explore the existence of asymmetric effects of independent variables on another economic variable. The model is formulated under the assumption of the presence of long and short-run asymmetry. Specifically, we consider the relationship between two data series $y_{t}$ and $x_{t}$ as the following asymmetric regression: 


$$
y_{t}=\beta^{+} x_{t}^{+}+\beta^{-} x_{t}^{-}+\varepsilon_{t}
$$

where $y_{t}$ is the dependent variable, meanwhile $x_{t}$ is a $(k \times 1)$ vector of the independent variable, and $\varepsilon_{t}$ is the random error term. The coefficients $\beta^{+}$and $\beta^{-}$represent asymmetric long-term parameters. Moreover, variable $x_{t}$ may be decomposed as:

$$
x_{t}=x_{0}+x_{t}^{+}+x_{t}^{-}
$$

Variable $x_{t}^{+}$and $x_{t}^{-}$are the partial sum of process positive and negative changes in $x_{t}$ which are formulated as follows:

$$
x_{t}^{+}=\sum_{i=1}^{t} \Delta x_{i}^{+}=\sum_{i=1}^{t} \max \left(x_{i}, 0\right) \quad \text { and } \quad x_{t}^{-}=\sum_{i=1}^{t} \Delta x_{i}^{-}=\sum_{i=1}^{t} \min \left(x_{i}, 0\right)
$$

Regarding the relationship between two data series $y_{t}$ and $x_{t}$, following Shin et al., (2014), we may formulate an error correction model in NARDL $(\mathrm{p}, \mathrm{q})$ which contains long and short-run asymmetric effects as follows:

$$
\Delta y_{t}=\alpha+\rho y_{t-1}+\theta^{+} x_{t-1}^{+}+\theta^{-} x_{t-1}^{-}+\sum_{j=1}^{p-1} \delta_{j} \Delta y_{t-j}+\sum_{j=0}^{q}\left(\pi_{j}^{+} \Delta x_{t-j}^{+}+\pi_{j}^{-} \Delta x_{t-j}^{-}\right)+\varepsilon_{t}
$$

The $\alpha$ is constant meanwhile the coefficient $\theta^{+}=-\rho \beta^{+}, \theta^{-}=-\rho \beta^{-}$, and the $\varepsilon_{t}$ is the residual. The terms $p$ and $q$ indicate the number of maximum lag length for the dependent and independent variables respectively. The optimum lag length of these variables may be determined using information criteria such as Schwarz Criterion (SC).

This research elaborates the asymmetric effects of government expenditure, money supply and exchange rate on the inflation rate. Therefore, we consider formulating the different individual equation model of inflation $\left(i n f_{t}\right)$ which contains independent variables of government expenditure $\left(g o v_{t}\right)$, money supply $\left(m s_{t}\right)$ and exchange rate $\left(e r_{t}\right)$ respectively. The models are mathematically formulated in Equation (4), (5) and (6) as follows.

$$
\begin{aligned}
& \Delta \inf _{t}=\alpha_{1}+\rho_{1} \inf _{t-1}+\theta_{1}^{+} \text {gov }_{t-1}^{+}+\theta_{1}^{-} \text {gov }_{t-1}^{-}+\sum_{j=1}^{p-1} \delta_{1 j} \Delta \inf _{t-j}+\sum_{j=0}^{q}\left(\pi_{1 j}^{+} \Delta \operatorname{gov}_{t-j}^{+}+\pi_{1 j}^{-} \Delta \operatorname{gov}_{t-j}^{-}\right)+\varepsilon_{1 t} \\
& \Delta \inf _{t}=\alpha_{2}+\rho_{2} \inf _{t-1}+\theta_{2}^{+} m s_{t-1}^{+}+\theta_{2}^{-} m s_{t-1}^{-}+\sum_{j=1}^{p-1} \delta_{2 j} \Delta \inf _{t-j}+\sum_{j=0}^{q}\left(\pi_{2 j}^{+} \Delta m s_{t-j}^{+}+\pi_{2 j}^{-} \Delta m s_{t-j}^{-}\right)+\varepsilon_{2 t} \\
& \Delta \inf _{t}=\alpha_{3}+\rho_{3} \inf _{t-1}+\theta_{3}{ }^{+} \operatorname{er}_{t-1}^{+}+\theta_{3}^{-} e r_{t-1}^{-}+\sum_{j=1}^{p-1} \delta_{3 j} \Delta \inf _{t-j}+\sum_{j=0}^{q}\left(\pi_{3 j}^{+} \Delta e r_{t-j}^{+}+\pi_{3 j}^{-} \Delta e r_{t-j}^{-}\right)+\varepsilon_{3 t}
\end{aligned}
$$


The terms $\alpha_{1}, \alpha_{2}, \alpha_{3}$ are the constants for each equation. The coefficients $\rho_{1}, \rho_{2}, \rho_{3}$ denote effects of previous inflation on the current inflation. The long-run impact of the increase of government expenditure, money supply, and the Rupiah depreciation on inflation changes are measured by $\theta_{1}^{+}, \theta_{2}^{+}, \theta_{3}^{+}$ respectively. On the other hand, the coefficients $\theta_{1}^{-}, \theta_{2}^{-}, \theta_{3}^{-}$measure the long-run impact of the increase of government expenditure, money supply, and the Rupiah depreciation on inflation changes. The coefficients $\delta_{1}, \delta_{2}, \delta_{3}$ denote the short-run effects of previous inflation changes on current inflation change.

Moreover, $\sum_{j=0}^{q} \pi_{j}^{+}$measure the short-run impacts of the increases of each mentioned independent variables on inflation changes, meanwhile the $\sum_{j=0}^{q} \pi_{j}^{-}$measure the short-run impacts of each independent variable reduction on inflation change. The terms $\varepsilon_{1 t}, \varepsilon_{2 t}, \varepsilon_{3 t}$ are the residual of each equation.

Based on the equations (4), (5) and (6), three possibilities asymmetric relationship may occur in each model: (1) the presence of only the long-run asymmetric relationship; (2) the existence of only short-run asymmetric effects; and (3) the empirical model captures both the long and short-run asymmetric relationship. To find what the best individual model is evaluated using the general-to-specific approach by eliminating the insignificant independent variables.

Since the equations capture the dynamic relationship, we should verify the presence of co-integrating relationship in among the set of variables. The next step is the analysis of the possibility of the long and short-run asymmetric impact of explanatory variables on the inflation variable. The presence cointegrating relationship in each model is tested using Bounds-test developed by Pesaran, Shin, \& Smith, (2001). The null hypothesis of no co-integrating relationship between inflation and other variables implies that the coefficients of the lagged level are jointly equal to zero. The null hypothesis is stated as $H_{0}: \rho=\theta^{+}=\theta^{-}=0$. The procedure of accepting or rejecting the null hypothesis uses the F-statistic approach. The F-statistic which is indicated by $F_{p s s}$ value should be compared to critical values of upper and lower bounds. If $F_{p s s}$ value is greater than the upper bound critical value, the null hypothesis of no cointegrating relationship should be rejected.

Next, we come to the process of analysis the existence of long and the short-run asymmetric effects of the explanatory variables on the inflation rate. For these purposes, this study applied a standard Wald restriction test in the empirical model for both long and short-run asymmetric effects. First, we conduct the testing for the presence of a long-run asymmetric relationship based on the null hypothesis statement as $H_{0}: \theta^{+}=\theta^{-}$. Based on a statistical procedure, the null hypothesis is rejected if the F-statistic is significant. Rejecting the null hypothesis indicates the presence of a long-run asymmetric relationship between explanatory variables and inflation rate. Moreover, in the second step, we also conduct a similar restriction test to elaborate on the existence of short-run asymmetric effects of independent variables on the inflation rate. The null hypothesis of short-run symmetry is stated as $H_{0}: \sum_{j=0}^{q} \pi_{j}^{+}=\sum_{j=0}^{q} \pi_{j}^{-}$. We reject the symmetric effects if the F-statistic is greater than its critical values. In such a condition, the short-run effects of explanatory variables on the inflation rate are asymmetry.

The asymmetric cumulative dynamic multipliers which describe the adjustment process from shortrun disequilibrium to its long-run equilibrium are formulated as follows:

$$
m_{k}^{+}=\sum_{j=0}^{k} \frac{\delta y_{t+j}}{\delta x_{t}^{+}}, m_{k}^{-}=\sum_{j=0}^{k} \frac{\delta y_{t+j}}{\delta x_{t}^{-}}, k=0,1,2 \ldots
$$


The term $m_{k}^{+}$and $m_{k}^{-}$are multiplier effects of each positive and negative changes of independent variables on the inflation rate (Equation 7). As $k \rightarrow \infty$ then $m_{k}^{+}$and $m_{k}^{-}$will equal with the asymmetric long-run coefficient $\beta^{+}$and $\beta^{-}$respectively.

This method has some advantages such as in estimating the short and long-run coefficients of the independent variable, providing the information of symmetric and asymmetric effects of the independent variable on a dependent variable, and presenting the cumulative dynamic multipliers of each independent variable. However, the limitation of this approach is that the estimated model is quite complex. Therefore, the analysis using this model only includes a limited number of the independent variables.

\section{EMPIRICAL RESULTS AND DISCUSSION}

The first step of this section presents the descriptive statistic of the data. The examined variables are the inflation rate $\left(i n f_{t}\right)$, government expenditure for final consumption $\left(g o v_{t}\right)$, money supply $\left(m s_{t}\right)$ and exchange rate $\left(e r_{t}\right)$. Descriptive statistic indicators such as mean, maximum, minimum and standard deviation of all variables are presented in Table 2. It also presents the values of positive (pos) and negative (neg) changes of three independent variables as a result of the estimation process based on the empirical NARDL model. The table indicates that all of the variables, except exchange rate, show low volatility, with a standard deviation less than the mean.

The maximum level of inflation rate in Indonesia reached 58.45 percent in 1998 as an impact of the deep financial crisis which started in 1997. Otherwise, the minimum inflation rate 3.52 percent which occurred in 2017 is the important indicator of the successful price stabilization policy in recent years. However, the average/mean of inflation rate for the period of 1970-2017 which achieve 11.15 percent may be classified as high inflation. The data on government expenditure and money supply have a statistical indicator at a moderate level. The exchange rate variable shows the extreme difference between its mean, maximum, and minimum. The mean value of this variable is 4978.54 indicating the low power of Indonesian currency. The maximum value which represents the lowest value of rupiah against the US dollar is $13,389.41$ which occurred in recent years. This variable could be assumed as one important key variable of price stabilization in the country.

Table 2

Descriptive statistic of variables

\begin{tabular}{|c|c|c|c|c|}
\hline Variables & Mean & Maximum & Minimum & $\begin{array}{c}\text { Standard } \\
\text { deviation }\end{array}$ \\
\hline inf $_{\mathrm{t}}(\%$ yearly) & 11.15 & 58.45 & 3.52 & 9.92 \\
\hline govt $\left(\%\right.$ of GDP) $^{\mathrm{ms}}$ (\% of GDP) & 9.17 & 12.03 & 5.69 & 1.46 \\
\hline er $_{\mathrm{t}}($ ratio Rp/US $\$)$ & 34.74 & 62.76 & 12.47 & 13.32 \\
\hline gov_pos & 4978.54 & 13389.41 & 391.87 & 4583.00 \\
\hline gov_neg & 27.64 & 35.42 & 14.23 & 6.02 \\
\hline ms_pos $_{\mathrm{t}}$ & -22.09 & -8.17 & -30.31 & 6.05 \\
\hline ms_neg $_{\mathrm{t}}$ & 95.09 & 161.34 & 3.11 & 56.54 \\
\hline er_pos & -110.98 & 0.00 & -192.63 & 65.79 \\
\hline er_neg & 115.25 & 246.50 & 1.03 & 88.82 \\
\hline & -158.82 & -43.14 & -295.48 & 91.01 \\
\hline
\end{tabular}

Source: World Development Indicators, 1970-2017 (https://data.worldbank.org). 
Since the NARDL model is part of a dynamic model, before estimating the empirical equation it is important to test the stationary of the data series. Although Ajaz, Nain, and Kamaiah (2016) note that the method may be used without considering the order of integration of the variables, we conduct the stationary testing for all of the variables. We employ an Augmented-Dickey-Fuller (ADF) procedure in a standard unit root test for a small sample. In this case, we estimate equations for unit root testing including the intercept. Table 3 presents the results that the data in level contains a unit root. It implies that the variables are non-stationary in the level. Moreover, the next results reveal that all variables are stationary in the first difference except the inflation rate at least at $5 \%$ level of significance. We conclude that all examined variables are integrated of order one.

Table 3

Results of unit root test

\begin{tabular}{|c|c|c|c|c|}
\hline \multirow{2}{*}{ Variables } & \multicolumn{2}{|c|}{ Level } & \multicolumn{2}{c|}{ First difference } \\
\cline { 2 - 4 } & t-statistic & p-value & t-statistic & p-value \\
\hline inf & 4.860 & 0.002 & -8.316 & 0.000 \\
\hline gov $_{\mathrm{t}}$ & -2.299 & 0.176 & -6.930 & 0.000 \\
\hline $\mathrm{ms}_{\mathrm{t}}$ & -1.717 & 0.416 & -3.809 & 0.005 \\
\hline er $\mathrm{r}_{\mathrm{t}}$ & -0.160 & 0.936 & -8.176 & 0.000 \\
\hline gov_pos & -2.778 & 0.068 & -8.614 & 0.000 \\
\hline gov_neg & -2.670 & 0.086 & -8.302 & 0.000 \\
\hline ms_pos & -1.223 & 0.656 & -7.193 & 0.000 \\
\hline ms_neg & -1.196 & 0.668 & -7.188 & 0.000 \\
\hline er_pos & 0.145 & 0.966 & -6.098 & 0.000 \\
\hline er_neg & -0.210 & 0.929 & -7.526 & 0.000 \\
\hline
\end{tabular}

Note: The optimal lag is based on the Schwartz Criterion (SC). All data series in level contain unit root except inflation. All the first difference data series are stationary.

The methodology of this study involves three steps; there is an analysis of the co-integrating relationship, the analysis of long and short-run asymmetric effects, and the estimation of the final empirical model. As the implication of dynamic analysis, we should conduct co-integrating relationship analysis among the set of variables. The F-statistic $\left(F_{P S S}\right)$ based on bound testing for three models are reported in the lower panel of Table 4. All the FPSS are greater than the upper level of bound critical value even though at the 1 percent level. Therefore, we reject the null hypotheses of no co-integrating relationship between government expenditure, money supply, exchange rate, and inflation rate respectively. It implies the presence of a long-run relationship between the inflation rate and these three variables. The evidence of the co-integrating relationship between the examined variables leads to the next analysis of a long and short-run dynamic asymmetric relationship. Therefore, we estimate three equations (4), (5) and (6) based on the general-to-specific approach of NARDL. The process of estimation starts by choosing $\max p=\max q=3$ and dropping all insignificant lags of independent variables. Table 3 summarizes the empirical estimates of these three equations. 
Results of NARDL estimation

\begin{tabular}{|c|c|c|c|c|c|c|}
\hline \multirow{2}{*}{$\begin{array}{c}\text { Coefficient } \\
\text { Constant }\end{array}$} & \multicolumn{2}{|c|}{$\begin{array}{c}\text { Effects of } \\
\text { government expenditure } \\
\text { (Model 4) }\end{array}$} & \multicolumn{2}{|c|}{$\begin{array}{c}\text { Effects of } \\
\text { money supply } \\
\text { (Model 5) }\end{array}$} & \multicolumn{2}{|c|}{$\begin{array}{c}\text { Effects of } \\
\text { exchange rate } \\
\text { (Model 6) }\end{array}$} \\
\hline & 45.37 & {$[2.11]^{* *}$} & 7.787 & {$[2.19]^{* * *}$} & 14.562 & [1.48] \\
\hline$\rho$ & -0.855 & {$[-62.0]^{* * *}$} & -0.767 & {$[-5.10]^{* * *}$} & -0.777 & {$[-3.64]^{* * *}$} \\
\hline$\theta^{+}$ & -5.966 & {$[-1.73]^{*}$} & 0.452 & {$[2.32]^{* *}$} & 0.067 & {$[0.27]$} \\
\hline$\theta^{-}$ & -5.738 & {$[-1.68]^{*}$} & 0.404 & {$[2.29]^{* *}$} & 0.096 & {$[0.41]$} \\
\hline$\delta_{1}$ & -0.095 & {$[-8.35]^{* * *}$} & -0.155 & {$[-1.22]$} & 0.332 & {$[1.83]^{*}$} \\
\hline$\pi_{0}^{+}$ & -1.004 & {$[-0.41]$} & 1.002 & {$[8.53]^{* * *}$} & 0.573 & {$[4.35]^{* * *}$} \\
\hline$\pi_{1}^{+}$ & -1.067 & {$[-0.49]$} & -0.361 & {$[-1.91]^{*}$} & 0.10 & {$[0.63]$} \\
\hline$\pi_{2}^{+}$ & & & -0.450 & {$[-2.29]^{* *}$} & & \\
\hline$\pi_{3}^{+}$ & & & 0.074 & [0.58] & & \\
\hline$\pi_{0}^{-}$ & -7.202 & {$[-3.05]^{* * *}$} & -0.147 & {$[-0.83]$} & 0.221 & {$[0.24]$} \\
\hline$\pi_{1}^{-}$ & 1.105 & {$[0.44]$} & -0.061 & {$[-0.36]$} & 0.130 & {$[0.25]$} \\
\hline R-squared & \multicolumn{2}{|c|}{0.99} & \multicolumn{2}{|c|}{0.86} & \multicolumn{2}{|c|}{0.67} \\
\hline F-statistic & \multicolumn{2}{|c|}{$1525.2^{* * *}$} & \multicolumn{2}{|c|}{$19.77 * * *$} & \multicolumn{2}{|c|}{$8.59 * * *$} \\
\hline$F_{p s s}$ & \multicolumn{2}{|c|}{$13.83^{* * *}$} & \multicolumn{2}{|c|}{$8.74 * * *$} & \multicolumn{2}{|c|}{$13.95^{* * *}$} \\
\hline $\begin{array}{c}\text { Long-run symmetry test: } \\
\qquad H_{0}: \beta^{+}=\beta^{-}\end{array}$ & \multicolumn{2}{|c|}{ F-stat: $3.66^{*}$} & \multicolumn{2}{|c|}{ F-stat: $4.69 * *$} & \multicolumn{2}{|c|}{ F-stat: $4.47^{* *}$} \\
\hline $\begin{array}{l}\text { Short-run symmetry } \\
\qquad H_{0}: \sum_{j=0}^{q} \pi_{j}^{+}=\sum_{j=0}^{q} \pi_{j}^{-}\end{array}$ & \multicolumn{2}{|c|}{ F-stat: 1.79} & \multicolumn{2}{|c|}{ F-stat: 2.27} & \multicolumn{2}{|c|}{ F-stat: 1.53} \\
\hline
\end{tabular}

Note: The final asymmetric NARDL specification is chosen using the general-to-specific approach which eliminates all insignificant variables in the model with a maximum lag length of 3 based on Schwarz Criterion (SC). $F_{p s s}$ is the F-statistic from the bounds-test for a co-integration relationship based on equation (4), (5), and (6). Values in the parentheses are t-statistic. The long and short-run symmetry tests use F-statistic. *, **, ${ }^{* *}$ indicate significant at $10 \%, 5 \%$ and $1 \%$ significance level, respectively.

The second step of the analysis is to verify the presence of the long and short-run relationship based on the empirical dynamic NARDL model from three equations respectively. The F-statistic based on Wald-test restriction test for a long-run symmetric relationship for three equations is greater than critical values at least at 10 percent significance level. It implies we reject the null hypothesis of an asymmetric relationship between government expenditure, money supply, exchange rate, and inflation rate respectively. The Wald-restriction test for symmetric short-run effects of these three variables individually on the inflation rate using gives an unexpected result. The null hypothesis of short-run symmetric effects of positive and negative components of the government expenditure, money supply, exchange rate on the inflation rate is not rejected. These findings present that the main response of fiscal and monetary policies, as well as the response of international factor on the inflation rate, are long-run asymmetry. This finding is in line with the previous research for the case of Iran (Falahi \& Hajamini, 2017). More specifically, the effect of increases and decreases in each variable (government expenditure, money supply, and exchange rate) of the same magnitude on inflation has a different magnitude. This means that the multiplier effect 
of the positive change and negative change in each variable on inflation is different as shown by the dynamic effect of each variable presented in Figures 1, 2, and 3. Likewise, the inflationary effects of both expansionary and contractionary monetary and fiscal policies tend to be not symmetry. This analysis reveals that the short-run effects of positive and negative change as the component of each variable namely government expenditure, money supply and exchange rate on inflation rate are symmetry. However, Ajaz, Nain, and Kamaiah (2016) found the existence of long and short-run asymmetric effects of exchange rate on inflation for Indian case. Table 5 presents a summary of the results analysis of the cointegrating relationship and the empirical estimates of the long and short-run asymmetric models.

Table 5

The summary of the symmetry test based on the empirical NARDL models

\begin{tabular}{|c|c|c|c|}
\hline Indicators & $\begin{array}{c}\text { Effects of } \\
\text { government expenditure }\end{array}$ & $\begin{array}{c}\text { Effects of } \\
\text { money supply }\end{array}$ & $\begin{array}{c}\text { Effects of } \\
\text { exchange rate }\end{array}$ \\
\hline Co-integration & Yes & Yes & Yes \\
\hline Long run effects & Asymmetry & Asymmetry & Asymmetry \\
\hline Short-run effects & Symmetry & Symmetry & Symmetry \\
\hline
\end{tabular}

The next analysis is to determine the three final empirical equations of inflation rate as a function of government expenditure, money supply, and exchange rate respectively. Based on the results as presented in Table 5, we estimate the empirical models of inflation rate which capture long-run asymmetric and short-run symmetric relationship. The long-run asymmetric relationship in the equation is indicated by positive and negative changes of each independent variable. On the other hand, the short-run symmetric effects are represented by each independent variable without its component of positive and negative changes. Following the general-to-specific approach, the best model is determined by eliminating the lags of the independent variable based on the Schwarz Criterion (SC). Table 5 presents the three final models of inflation rate which has a different independent variable.

The analysis of the relationship between government expenditure and the inflation rate is based on the long-run asymmetric NARDL model as presented in Table 6 . The coefficient of a positive $\left(\theta^{+}\right)$and negative $\left(\theta^{-}\right)$component of government expenditure is negative and significant at the 0.10 level. Meanwhile, the coefficient $\pi_{0}$ is also negative and significant at the 0.05 level. It may be explained some reasons regarding the negative relationship between government consumption growth and the inflation rate in Indonesia. At the beginning of the 1970s, the inflation rate is about 40 percent as an impact of political instability. As a result, the central government maintained its expenditure at low growth for several years. Finally, the inflation rate gradually dropped for several years and achieve at an average of 10 percent annually.

The interpretation of the impact money supply on inflation rate is based on the long-run asymmetric and short-run symmetric relationship as presented in Table 5 . The coefficient of positive component $\left(\theta^{+}\right)$ and negative component $\left(\theta^{-}\right)$of money supply are statistically significant at 0.01 level. The estimated coefficient of $\theta^{+}$is 1.094 implying that one percent increase of money supply growth leads to rising inflation rate at about 1.1 percent. The coefficient $\theta^{-}$is 0.999 indicating the decrease of money supply growth of 1 percent causes the lower inflation rate at 1 percent also. In the short term, the impact of money supply growth on inflation is expressed by the coefficient of the change of money supply growth. The estimated coefficient of $\pi_{0}$ is 0.683 implying the change of money supply growth about 1 percent 
leads to an increase in the inflation rate at about 0.7 percent yearly. This paper concludes that the inflation rate in Indonesia strongly depends on the monetary sector changes. These findings are in line with the previous studies which used data from emerging economies such as India and selected Asian countries (Bhattacharya, 2014; Mohanty \& John, 2015). This also implies that changes in prices are sensitive to changes in monetary policy, except that there is no way to say which one is more powerful, expansionary or contractionary monetary policies, in influencing the changes in prices. This issue will be addressed in the analysis of the dynamic effect of each variable on inflation later on.

Table 6

The final estimates of the long-run NARDL asymmetric model

\begin{tabular}{|c|c|c|c|c|c|c|}
\hline \multirow{2}{*}{$\begin{array}{c}\text { Coefficient } \\
\text { Constant } \\
\end{array}$} & \multicolumn{2}{|c|}{$\begin{array}{c}\text { Effects of } \\
\text { government expenditure: } \\
\text { long run asymmetry }\end{array}$} & \multicolumn{2}{|c|}{$\begin{array}{c}\text { Effects of } \\
\text { money supply: } \\
\text { long run asymmetry }\end{array}$} & \multicolumn{2}{|c|}{$\begin{array}{c}\text { Effects of } \\
\text { exchange rate: } \\
\text { long run asymmetry }\end{array}$} \\
\hline & 56.94 & {$[2.61]^{* *}$} & 16.89 & {$[4.21]^{* * *}$} & 24.72 & {$[3.25]^{* * *}$} \\
\hline$\rho$ & -0.851 & {$[-4.46]^{* * *}$} & -0.887 & {$[-4.65]^{* * *}$} & -0.494 & {$[-3.17]^{* * *}$} \\
\hline$\theta^{+}$ & -6.466 & {$[-1.85]^{*}$} & 1.094 & {$[3.78]^{* * *}$} & 0.395 & {$[2.41]^{* *}$} \\
\hline$\theta^{-}$ & -5.937 & {$[-1.72]^{*}$} & 0.999 & {$[3.89]^{* * *}$} & 0.407 & {$[2.53]^{* *}$} \\
\hline$\delta_{1}$ & 0.124 & {$[0.79]$} & 0.211 & [1.41] & 0.050 & {$[0.70]$} \\
\hline$\pi_{0}$ & -3.650 & {$[-2.17]^{* *}$} & 0.683 & {$[6.21]^{* * *}$} & 0.442 & {$[4.67]^{* * *}$} \\
\hline$\pi_{1}$ & 1.046 & {$[0.63]$} & -0.387 & {$[-2.01]^{* *}$} & 0.071 & {$[0.79]$} \\
\hline$\pi_{2}$ & & & -0.324 & {$[-2.43]^{* *}$} & & \\
\hline$\pi_{3}$ & & & -0.097 & {$[-0.92]$} & & \\
\hline R-squared & \multicolumn{2}{|c|}{$\frac{1}{0.48}$} & \multicolumn{2}{|c|}{0.74} & \multicolumn{2}{|c|}{0.62} \\
\hline F-statistic & \multicolumn{2}{|c|}{$6.16^{* * *}$} & \multicolumn{2}{|c|}{$12.19^{* * *}$} & \multicolumn{2}{|c|}{$11.43^{* * *}$} \\
\hline Schwarz Criterion & \multicolumn{2}{|c|}{7.61} & \multicolumn{2}{|c|}{7.10} & \multicolumn{2}{|c|}{7.27} \\
\hline Serial Correlation LM Test & \multicolumn{2}{|c|}{ Prob. $F(2,39): 0.60$} & \multicolumn{2}{|c|}{ Prob. F(2,39): 0.89} & \multicolumn{2}{|c|}{ Prob. $F(2,39): 0.55$} \\
\hline $\begin{array}{c}\text { Heteroskedasticity Test: } \\
\text { ARCH }\end{array}$ & \multicolumn{2}{|c|}{ Prob. $F(1,45): 0.93$} & \multicolumn{2}{|c|}{ Prob. $F(1,41): 0.85$} & \multicolumn{2}{|c|}{ Prob. $F(6,41): 0.13$} \\
\hline
\end{tabular}

Note: The final empirical model is chosen using the general-to-specific approach which eliminates all insignificant variables in the model with a maximum lag length of 3 lags based on Schwarz Criterion (SC). Values in the parentheses are t-statistic except in serial correlation and heteroskedasticity test. All the empirical models do not contain serial correlation and heteroskedasticity. *,**, *** indicate significant at 10\%, 5\% and 1\% significance level, respectively.

The long-run impact of exchange rate on inflation rate is also indicated by the significance of the coefficient of its positive $\left(\theta^{+}\right)$and negative $\left(\theta^{-}\right)$components. Both of this coefficient is statistically significant at the 0.05 level. It implies that the depreciation of the Indonesian currency leads to a higher inflation rate. The estimated coefficient of $\theta^{+}$is 0.395 indicating that inflation rate raises at about 0.4 percent as an impact of the depreciation of rupiah in one percent. In the short term, the impact of the local currency depreciation on the inflation rate is also statistically significant at the 0.01 level. In the case of the rupiah depreciated 1 percent against the US dollar, the inflation rate increase at about 0.44 percent. These findings reveal that the international factor contributes to the inflation rate in Indonesia. This is consistent with the empirical findings on the pass-through effects of exchange rate on inflation in Indonesia, which confirm the positive effect of depreciation rate on the inflation rate. This is not surprising since imported components in consumption, capital, and intermediate goods are quite significant. Accordingly, the central bank cannot ignore the depreciation rate in conducting its monetary policy that targets inflation rate. The central bank has to include the depreciation rate in its monetary policy reaction function as one of the variables whose movements are monitored in setting the policy rate. 
Moreover, Fakher, (2016) also mentions that the exchange rate has a significant impact of inflation in selected Asian countries.

The dynamic effects of government expenditure, money supply and exchange rate on inflation rate are depicted by dynamic multipliers as presented in Figure 3, Figure 4, and Figure 5. The dynamic effects of positive and negative changes in government expenditure and the exchange rate on inflation are stable during the second period. The dynamic effects of money supply reach its stability and symmetry at fourth periods. The gap between the positive and negative effects of money supply and exchange rate on inflation also reach their maximum in the second period. The dynamic multiplier effects of government expenditure are greater than those of the money supply and exchange rate for two years.

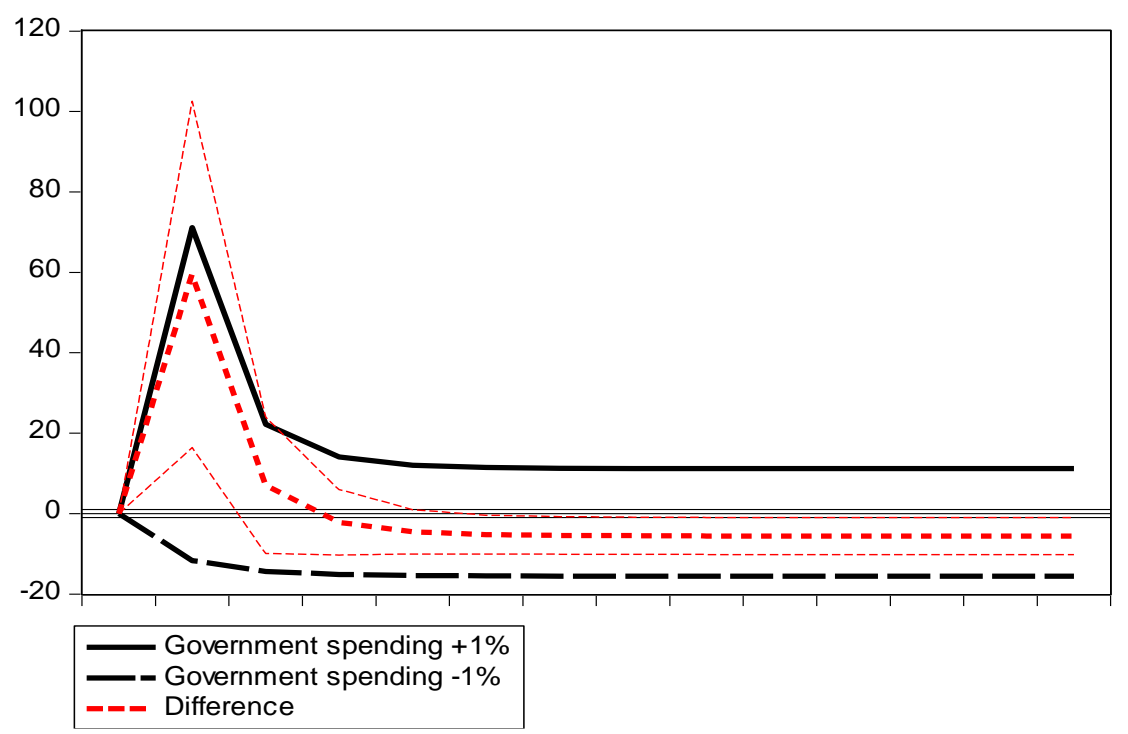

Figure 3. Dynamic multipliers of government expenditure on inflation

Specifically, the dynamic effects of positive and negative changes in government spending on inflation as presented in Figure 3 exhibit the interesting phenomena. First, the gap between positive and negative change in government spending at the beginning of the period is quite high and over the horizon. Then, starting in the third year it shrinks until at the end of the period. Second, it also in the beginning period, the dynamic effect of positive change in government spending is much greater than negative change. Third, it could be inferred that the positive change in government spending or the increase in government consumption directly leads to higher inflation in the next year. These results confirm the fiscal theory of price level (FTPL) which generally state that the fiscal expansion causes higher inflation in a large emerging economy (Hashem, 2018; Tran, 2018). We may infer that in the long-run the fiscal expansion is not inflationary. 


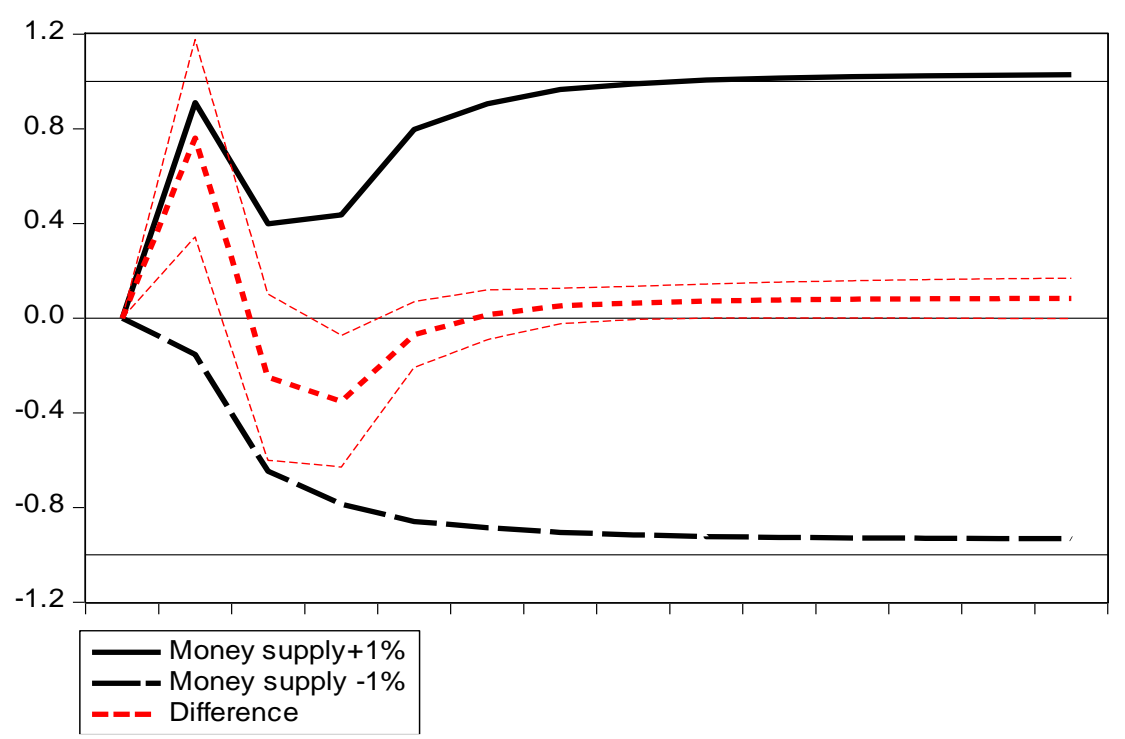

Figure 4. Dynamic multipliers of money supply on inflation

A monetarist theory states that the increase in money supply will cause price change. Figure 4 plots the dynamic effect of positive and negative changes in the money supply on the inflation rate. The multiplier effects of money supply on inflation in this study describe the relevance of these findings with the monetarist proposition. At the beginning period, the dynamic effect of positive change in money supply on inflation is quite high. Even though it decreases in the second year, but it rises back starting in the fourth year and stable until at the end of the period of the analysis. The gap between positive and negative change in the money supply is relatively high during the first three years. It decreases starting in the fourth year and stable at a low level until at the end of the period. This difference value between positive and negative change in money supply is positive indicating that the effect of money supply on inflation is asymmetry (Güney, 2018). It may be inferred that these findings are part of the area of classical economic theory. Therefore, money supply targeting is an effective instrument in stabilizing the price level.

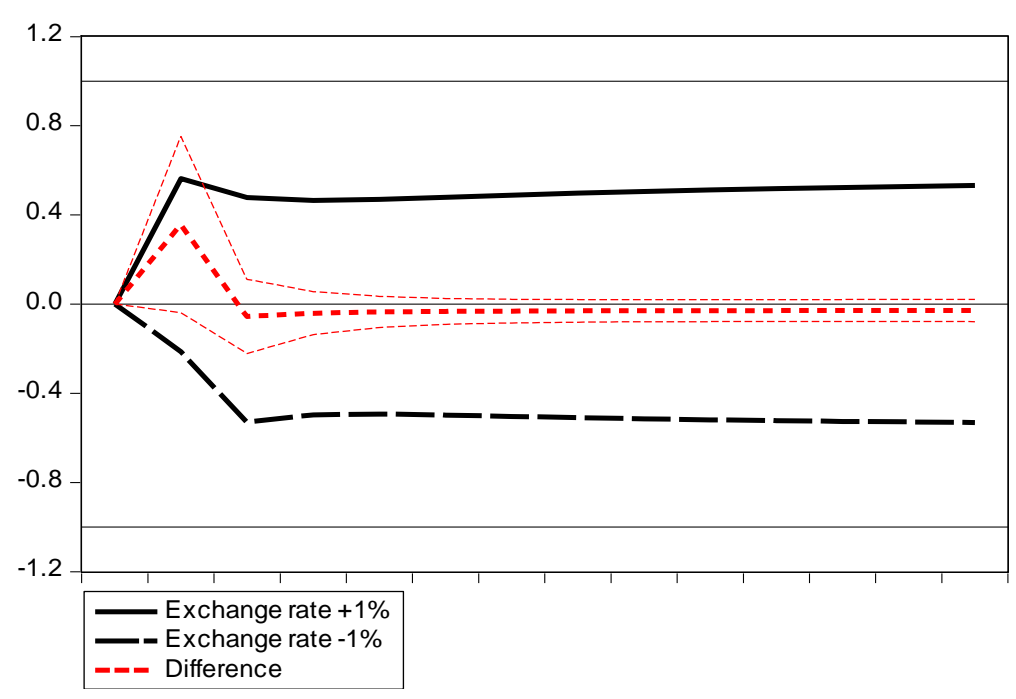

Figure 5. Dynamic multipliers of the exchange rate on inflation 
The international factor such as the volatility of the global financial market may be considered as a determinant of inflation rate in some countries through exchange rate instrument. The dynamic effect of exchange rate on inflation as presented in Figure 5 supports the strong effect of exchange rate volatility on inflation in the Indonesian case. The gap between positive and negative change in the exchange rate which also indicates the asymmetric effect is at the high level in the first year. Moreover, the positive change in the exchange rate, that is the depreciation of the rupiah, has an impact on the inflation rate starting in the first year. It implies that the depreciation of the Indonesian currency leads to higher inflation in the next year. These results confirm the significant role of international factor especially exchange variable on domestic inflation. Overall, it may be inferred that the pattern of these multiplier effects supports the long-run asymmetric effect of government spending, money supply, and exchange rate on inflation.

Overall, the results imply that expansionary fiscal policy is more potent in increasing inflation than the contractionary fiscal policy in reducing the inflation rate. Accordingly, the government should be more concerned about the inflationary effect of fiscal expansion. The same can be said about the monetary expansion that is more inflationary than the monetary contraction that results in a smaller reduction in inflation (Güney, 2018). Similarly, the government needs to be more careful about the inflationary effect of the depreciation of the rupiah than about the deflationary effect of the appreciation of the currency.

\section{CONCLUSION}

This paper examines the effects of government expenditure, money supply and exchange rate on the inflation rate for the Indonesian case. The study uses an asymmetric approach of the nonlinear autoregressive distributed lag model (NARDL). The findings present the long-run asymmetric relationship between these three variables and inflation rate respectively. Moreover, the short-run effects of the variables on the inflation rate are symmetry. Government expenditure does not statistically affect the inflation rate. Meanwhile, the money supply and exchange rate strongly influence the inflation rate yearly. We also conclude that positive and negative changes in either the money supply or exchange rate lead to annual inflation changes. The results also imply that the inflation rate is closely related to the monetary sector. Therefore, monetary policies and international factor play an important role in price stabilization in Indonesia.

The long-run asymmetric relationship between money supply and inflation rates implying the effects of expansive and contractive monetary policy on the inflation rate are asymmetry. The component of positive changes in the money supply leads to raising the inflation rate higher than that of the negative component. Symmetric effects of money supply on inflation rate in the short-term indicate that the monetary policy is effective in stabilizing the price level. This study also highlights that the exchange rate significantly contributes to the increase in the inflation rate. The strong positive linkage between the monetary sector and inflation is also in line with the neo-classical economic theory.

Previous studies regarding the determinant of the inflation rate have not considered the role of asymmetric responses. Therefore, this paper contributes to the recent literature by providing an asymmetric response of fiscal and monetary policies on the inflation rate. We may infer that monetary policy will be effective in price stabilization. In the Indonesian context, the central bank should apply a prudential monetary policy to avoid high inflation.

\section{ACKNOWLEDGMENT}

The author would like to thank the Center of Economics Studies, Department of Economics, Islamic University of Indonesia for providing the fund for this research under the scheme of Applied Research Grant No. 7/Dir.PPE/II/2018. 


\section{REFERENCES}

Ajaz, T., Nain, M. Z., \& Kamaiah, B. (2016). Inflation and openness in India: an asymmetric approach. Macroeconomics and Finance in Emerging Market Economies, 9(2), 190-203. doi:10.1080/17520843.2016.1162825

Berument, H., \& Dogan, B. (2003). Openness and the effectiveness of monetary policy: empirical evidence from Turkey. Applied Economics Letters, 10(4), 217-221. doi:10.1080/1350485022000015842

Bhattacharya, R. (2014). Inflation dynamics and monetary policy transmission in Vietnam and emerging Asia. Journal of Asian Economics, 34, 16-26. doi:10.1016/j.asieco.2014.05.001

Bozkurt, C. (2014). Money, inflation and growth relationship: The Turkish case. International Journal of Economics and Financial Issues, 4(2), 309-322.

Fakher, H. (2016). The empirical relationship between fiscal deficits and inflation (Case study: Selected Asian economies). Iranian Economic Review, 20(4), 551-579.

Falahi, M. A., \& Hajamini, M. (2017). Asymmetric behavior of inflation in Iran: new evidence on inflation persistence using a smooth transition model. Iranian Economic Review, 21(1), 101-120. doi:10.1684/MRH.2014.0363

Findreng, J. H. (2014). Relative purchasing power parity and the European monetary union: evidence from eastern Europe. Economics and Sociology, 7(1), 22-38. doi:10.14254/2071-789X.2014/7-1/3

Gali, J. (2010). Inflation pressures and monetary policy in a global economy. International Journal of Central Banking, $6(1), 93-102$.

Ghosh, A. (2014). How do openness and exchange-rate regimes affect inflation? International Review of Economics \& Finance, 34, 190-202. doi:10.1016/j.iref.2014.08.008

Güney, P. Ö. (2018). Asymmetries in monetary policy reaction function and the role of uncertainties: the case of Turkey. Economic Research-Ekonomska Istrazivanja, 31(1), 1367-1381. doi:10.1080/1331677X.2018.1481445

Halka, A., \& Szafranski, G. (2018). What common factors are driving inflation in cee countries? Prague Economic Papers, 27(2), 131-148.

Hamilton, J. D. (2012). Import prices and inflation. International Journal of Central Banking, 8(1), 271-280.

Hashem, H. Y. M. (2018). Inflation in Egypt: a fiscal or monetary phenomenon? Business and Economic Horizons, 13(4), 522-535. doi:10.15208/beh.2017.36

Hossain, A. (2005). The sources and dynamics of inflation in Indonesia: An ECM model estimation for 1952-2002. Applied Econometrics and International Development, 5(4), 93-116.

Insukindro, \& Sahadewo, G. A. (2010). Inflation dynamics in Indonesia: equilibrium correction and forward-looking Phillips curve approaches. Gadjah Mada International Journal of Business, 12(1), 117-133.

Khundrakpam, J. K., \& Pattanaik, S. (2010). Fiscal stimulus and potential inflationary risks: an empirical assessment of fiscal deficit and inflation relationship in India. Journal of Economic Integration, 25(4), 703-721.

Kumar, S. (2015). Inflation, uncertainty and monetary policy in India: a regime-switching analysis. Economics Bulletin, 35(4), 2213-2219.

Lakić, S., \& Šehović, D. (2016). An analysis of the official dollarization regime in Montenegro: theoretical approaches and empirical evidence. Journal of International Studies, 9(2), 48-64. doi:10.14254/2071-8330.2016/9-2/3

Meyer, D. F., Sanusi, K. A., \& Hassan, A. (2018). Analysis of the asymmetric impacts of oil prices on food prices in oil-exporting developing countries. Journal of International Studies, 11(3), 82-94. doi:10.14254/2071$8330.2018 / 11-3 / 7$

Mohanty, D., \& John, J. (2015). Determinants of inflation in India. Journal of Asian Economics, 36, 86-96. doi:10.1016/j.asieco.2014.08.002

Nguyen, V. B. (2015). Effects of fiscal deficit and money M2 supply on inflation: evidence from selected economies of Asia. Journal of Economics, Finance and Administrative Science, 20, 49-53. doi:10.1016/j.jefas.2015.01.002 
Nikolaos, A., \& Constantinos, K. (2013). A dynamic panel, empirical investigation on the link between inflation and fiscal Imbalances. Does heterogeneity matter? Prague Economic Papers, 2, 147-162.

Pesaran, M. H., Shin, Y., \& Smith, R. J. (2001). Bounds testing approaches to the analysis of level relationships. Journal of Applied Econometrics, 16(3), 289-326. doi:10.1002/(ISSN)1099-1255

Raji, J. O., Juzhar, J., \& Jantan, M. D. (2014). Real money supply, price and fiscal deficit in Nigeria: Evidence from multivariate Granger causality tests. Journal of Economic Cooperation and Development, 4(4), 85-112.

Shin, Y., Yu, B., \& Greenwood-Nimmo, M. (2014). Modeling asymmetric cointegration and dynamic multipliers in a nonlinear ARDL framework. (W. C. Horrace \& R. C. Sickles, Eds.)In Festschrift in Honor of Peter Schmidt. New York: Springer.

Tran, N. (2018). Asymmetric effects of fiscal balance on monetary variables: evidence from large emerging economies. Empirical Economics, (November), 1-32. doi:10.1007/s00181-018-1483-y

Zwolankowski, M. (2013). The financial crisis, financial system instability and monetary transmission mechanism. Journal of International Studies, 4(1), 26-32. doi:10.14254/2071-8330.2011/4-1/3 